\title{
The Effect of Leadership and Incentives on Employee Performance of Market Retribution
}

\author{
Dona Doni ${ }^{1}$ Morris Adidi Yogia ${ }^{1 *}$ Zainal $^{1}$ Made Devi Wedayanti ${ }^{1}$ Astri Ayu Purwati ${ }^{2}$ \\ ${ }^{1}$ Universitas Islam Riau, Indonesia \\ ${ }^{2}$ Institut Bisnis dan Teknologi Pelita Indonesia, Indonesia \\ ${ }^{*}$ Corresponding author. Email: moris.adidiy@soc.uir.ac.id
}

\begin{abstract}
In optimizing regional revenue sourced from the local retribution, the biggest problem that can hamper the optimization of regional acceptance is the factor of the quality of human resources (HR) as well as regional managerial ability in managing the Regional Tax and Retribution which is still not optimal. Therefore, this study aims to analyze the effect of leadership and incentives on the performance of the Pelita market retribution employee at Bangko District, Rokan Hilir Regency. The population in this study were employees / market apparatus of the Pelita District Bangko market and traders selling at the Pelita market Bangko District Rokan Hilir District, amounting to 30 people, given the limited population, this study used a total of 30 employees as samples. The results showed that the leadership variable had a significant effect on the performance of the Pelita market retribution employee in Bangko Subdistrict, Rokan Hilir District, as well as the incentive variable had a significant influence on the performance of Pelita market employee in the Bangko Subdistrict, Rokan Hilir District.
\end{abstract}

Keywords: Leadership, incentives, performance, market retribution.

\section{INTRODUCTION}

With the implementation of the current regional autonomy system, there are opportunities and challenges that the current regional government must have. Regional autonomy has provided ample opportunities for local governments to be able to access the potential of a region to increase regional revenue. All resources must be utilized optimally to accelerate development so as not to be left behind by other regions. Apart from being an opportunity for autonomy, it is also a challenge that must be had by regions to be able to depend on the regional government so far as the central government, and also to accelerate the realization of people's welfare. Prior to the stipulation of regional autonomy, regional planning and planning had been more regulated by the government with a top down mecansm planning pattern. All central government planning for co-administration and local governments that carry out. BUT with the implementation of regional autonomy and the participation of the central government, regional governments are given the freedom of the government to help their own regions to accelerate development [1].

In principle, local levies are managed independently by each region, because in the management of this regional levy, there may be differences in the system or method used by each region. One form of regional levies is market service levies. This market service levies are in accordance with Law No. 28/2009 article 110 paragraph $1 \mathrm{f}$ classified in the types of public service fees that make a potential contribution to the development and welfare of the community. For this reason, the Regional Government must really use the results of the Market Service Retribution as well as possible [2]. Regional managerial ability in managing the Regional Tax and Retribution is still not optimal. This condition will certainly directly impact on the non-optimism of blood revenues through regional taxes and charges. On the other hand, the stipulation of regional autonomy requires regional governments to be able to finance various government and development activities with their own capabilities. This means that regions are no longer dependent on funds or subsidies from the central government, where the amount is very limited for some regions.

There are several factors that affect the performance of civil servants in managing market fees, one of which comes from the managerial aspect of the leader, in this case the Regional Government of Rokan Hilir Regency to try to improve funding budgeting in an effort to manage market service fees. The ability of the organizational leadership of the Rokan Hilir Regency Market and Trade Industry Service in the Management of Pelita Market Retribution, Bangko District, is very influential in increasing Rokan Hilir Regency Original Revenue. Several previous studies have examined the importance of the role of leadership in improving employee performance, including research by [3][4][5] where the results of this study indicate that leadership has an influence on employee performance.

Apart from leadership, incentives also play an important role in determining whether or not employee performance is good, because incentives are a motivation for someone as a form of appreciation for what has been produced. Until now, the provision of incentives for collectors of market service fees in the Pelita market and also officials in charge 
of market service fees has not been implemented by the Rokan Hilir Regency Trade and Market Industry Service, this condition occurs because of the limited funding budget budgeted by the Rokan Hilir Regency Government. With the absence of the incentives given, the efforts to implement or mobilize (actuating) and motivate the morale of the officers cannot run properly so that the optimization and effectiveness of the work of officers who manage market service fees are not carried out properly. Several previous studies have shown that incentives have a significant effect on employee performance [6].

\section{LITERATURE REVIEW}

\subsection{Leadership on employee performance}

In a company, leadership is one of the main factors that support the company's success in achieving its goals. The company will succeed or even fail is largely determined by leadership. Leadership is an art, because the approach of each person in leading others can be different depending on the characteristics of the leader, the characteristics of the task, and the characteristics of the person they lead. A good leader will be able to lead and direct employees to do work in an acceptable way without feeling forced.

According to [7], leadership is a way for a leader to influence the behavior of subordinates, so that they are willing to work together and work productively to achieve organizational goals. In order to streamline the regulations issued in order to enforce discipline, it is necessary to have an example of leadership [8]. Leadership has a huge influence in enforcing discipline, because leaders are role models and highlights from their subordinates. With an exemplary leader, it is hoped that employees will be more disciplined, not just afraid of punishment, but even more so because they are reluctant / shy of their exemplary leaders. Leadership is basically a study of individuals who have physical, mental, and position characteristics that are considered more than other individuals in a group who are considered to be able to influence other individuals to act in the direction of achieving goals. [9] states that leadership is a way of getting employees to act right, to achieve commitment and to motivate them to achieve common goals.

Based on research by [3][4][5] states that partially leadership has a positive and significant effect on employee performance.

$\mathrm{H}_{1}=$ Leadership affects the performance of market retribution employees

\subsection{Incentives for Employee Performance}

Hasibuan states that incentives are additional remuneration given to certain employees whose performance is above standard performance [7]. This incentive is a tool used to support the fair principle in providing compensation. According to [10], incentives are a form of motivation expressed in the form of money on the basis of high performance and also a sense of recognition from the organization of employee performance and contributions to the organization or company.
Walumbwa et al., stated that the incentive system in the conceptual framework is seen as a combination of both financial and non-financial incentives provided by companies in achieving single individual and group targets as a result of collective responsibility by professional teams in the success of the task given [11].

Currently, the need for good performance management is felt to be increasingly important in various companies to encourage motivation and commitment and to develop employee performance. Because a good job appraisal will also encourage organizational rewards (rewards), such as bonuses / incentives, salary increases or promotions for employees. These various rewards will ultimately satisfy the employee's personal goals.

If employees see that hard work and superior performance are recognized and rewarded by the company, they will expect such a relationship to continue in the future. Therefore, they will determine a higher level of performance that expects a higher level of compensation. $\mathrm{H} 2$ = Incentives affect the performance of market retribution employees

\subsection{Thinking Framework and Hypotheses}

The framework for this research is as follows:

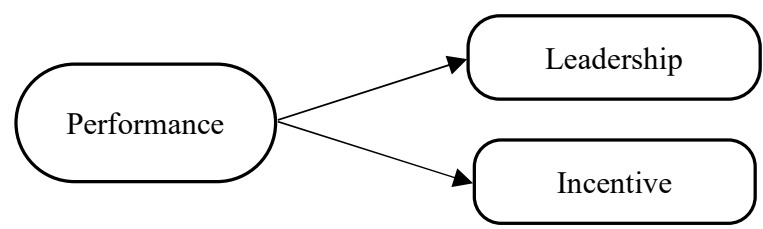

Figure 1 Framework

Based on this framework, the research hypothesis is formulated as follows:

$\mathrm{H} 1=$ Leadership has a positive and significant effect on the performance of market retribution employees

$\mathrm{H} 2=$ Incentives have a positive and significant effect on the performance of market retribution employees.

\section{METHOD}

\subsection{Population and Sample}

The population in this study were 30 employees of the Pelita market retribution, Bangko District. For this reason, the research sample used a sensory method so that the sample taken in this study was the entire population, namely 30 employees.

\subsection{Research Instrument}

To measure the value of the variable under study, a research instrument was used. The research instrument used aims to be able to produce accurate quantitative data. In this study, the instrument that the researchers used was a questionnaire. In each statement listed in the questionnaire, the researcher provides a measurement scale. The scale of measurement of variables that researchers use is the Likert scale. Likert scale is a scale that distinguishes certain categories with certain 
distances and the distance between the same categories. The Likert scale has no absolute zero. The statement indicators used in this study consist of: 1) leadership variables consisting of skills, personality, experience, intellectuals and work environment. 2) Incentive variables consisting of piecework, production bonuses, commissions, people skills. 3) Performance variables consist of quality of work, quantity of work, timeliness and work discipline.

\subsection{Multiple Linear Regression Analysis}

In an effort to answer the problems in this study, multiple linear regression analysis is used. Multiple linear regression analysis is a linear relationship between two or more independent variables $(\mathrm{X} 1, \mathrm{X} 2, \mathrm{X} 3, \ldots \mathrm{Xn})$ with the dependent variable $(Y)$. The equation model used in this study is $\mathrm{Y}=\mathrm{a}+\beta 1 \mathrm{X} 1+\beta 2 \mathrm{X} 2+\beta 3 \mathrm{X} 3+\mathrm{e}$.

\subsection{Hypothesis testing}

To find out whether or not there is an influence of the independent variable on the dependent variable, testing the proposed hypothesis is carried out by simultaneously testing using the $\mathrm{F}$ test, and partial testing using the $\mathrm{t}$ test.

The $\mathrm{F}$ test basically shows whether all independent variables entered in the model have a joint influence on the dependent variable. It is said together - independent variables affect the dependent variable if Ftable $<$ Fcount at $\alpha=5 \%$.

The coefficient of determination (R2) is used to explain the proportion of the dependent variable that can be explained by the variation of the independent variables. The coefficient of determination is between zero and one. Many researchers recommend using the Adjusted R Square value when evaluating the best regression model.

$\mathrm{T}$ test is used to test the significance of the relationship between the independent variable $(\mathrm{X})$ partially significant effect or not on the dependent variable (Y). It is said that the independent variable partially influences the dependent variable if $\mathrm{t}$ table $<\mathrm{t}$ arithmetic at $\alpha=5 \%$.

\section{RESULT AND DISCUSSION}

\subsection{Simultaneous Significance Test (Test F)}

The $\mathrm{F}$ test is to determine whether the employee placement, compensation and workload variables together have a significant influence on employee performance at Pelita market retribution, it is necessary to do simultaneous testing or $\mathrm{F}$ test. The proposed hypothesis model is: $\mathrm{H} 1: \beta 1=\beta 2=$ $\beta 3 \neq 0$, meaning that the variables of leadership and incentives simultaneously affect the performance of market retribution employees.

Table 1 Simultaneous Test of Significance

\begin{tabular}{|rl|r|r|r|r|r|}
\hline & Model & Sum of Squares & Df & $\begin{array}{c}\text { Mean } \\
\text { Square }\end{array}$ & F & Sig. \\
\hline 1 & Regression & 7.624 & 2 & 2.541 & 30.394 & $.000^{\mathrm{a}}$ \\
& & 4.097 & 28 & 0.084 & & \\
Residual & 11.721 & 30 & & & \\
Total &
\end{tabular}

Source: Research Results

From the results of simultaneous testing, the Fcount result is 30.394 while the Ftable value is 2.794 , so $\mathrm{H} 0$ is rejected and $\mathrm{H} 1$ is accepted, which means that together leadership and incentives affect the performance of market retribution employees.

\subsection{Koefisien Determinasi (R2)}

The coefficient of determination is used to see the ability of the independent variable to explain the dependent variable, where if the $\mathrm{R}$ square value approaches one, the independent variable provides all the information needed to predict the variation in the dependent variable.

Table 2 Coefficient of Determination $\left(\mathrm{R}^{2}\right)$

\begin{tabular}{|r|c|r|r|r|} 
& & & & \\
Model & $\mathrm{R}$ & R Square & Adjusted R Square & Std. Error of the Estimate \\
\hline 1 & $.807^{\mathrm{a}}$ & 0.650 & 0.629 & 0.28916 \\
\hline
\end{tabular}

Source: Research Results

From the processing results, it is known that the coefficient of determination (Adjusted R square) is 0.629. This means that $62.9 \%$ of employee performance can be explained by leadership and incentive variables, while the remaining $37.1 \%$ of employee performance is influenced by other variables not examined in this study.
This shows that the influence of leadership and incentives on employee performance at market retribution employee is quite high. 


\subsection{Partial Test ( $t$ test)}

The $t$ test is used to determine the partial effect of independent variables (employee placement, compensation and workload) on the dependent variable (employee performance). Statistical calculations in the multiple linear regression analysis used in this study were to use the help of the SPSS for Windows version 16 computer program. The following will explain the partial testing of each variable in table 4:18 below:

Table 3 Partially Significant Test
\begin{tabular}{|c|c|c|c|c|}
\hline \multicolumn{2}{|c}{ Model } & T & Sig. & Information \\
\hline \multirow{4}{*}{1} & (Constant) & 3.653 & .001 & \\
\cline { 2 - 5 } & Leadership (X1) & 3.116 & .003 & Influential and Significant \\
\cline { 2 - 5 } & Incentive (X2) & 2.809 & .007 & Influential and Significant \\
\hline
\end{tabular}

Source: Research Results

From the table above, the partial test results can be explained as follows:

The test results show that the $\mathrm{t}$ value for the employee placement variable 3,116 is greater than the $t$ table 2,010 or a significant value of 0,000 is smaller than $0.25 \%$ alpha. then the hypothesis can be accepted. The direction of the positive regression coefficient means that leadership has a significant positive effect on the performance of market retribution employees. in other words, better leadership will improve employee performance. In addition, the results show that the $t$ value for compensation of 2,809 is greater than the t table of 2010 or the significant value of 0,000 is smaller than the alpha of $0.025 \%$. then the hypothesis can be accepted. The direction of the positive regression coefficient means that the incentive has a significant positive effect on the employee performance of market retribution.

\subsection{The influence of leadership on the performance of market retribution employees}

The results showed that leadership has a significant influence on the performance of the Pelita market retribution employees, Bangko District, Rokan Hilir Regency. Based on the results of research as well as the results of observations / observations that have been carried out at the Office of Industry, Trade and Market of Rokan Hilir Regency and also at the location of the Pelita market, Bangko District regarding Organizing (Organizing) in the management of Pelita market charges, actions are carried out in an effort to achieve the target of receiving retribution as well as the satisfaction of the executors of the Pelita market service retribution, Bangko District, in the Good Enough category. This shows that the Office of Industry, Trade and Markets of Rokan Hilir Regency as the management agency for Pelita market service fees has not been able to carry out its function properly. The ability of the organizational leadership of the Rokan Hilir Regency Trade and Market Industry Service in Managing the Pelita Market Levies in Bangko District in Increasing Rokan Hilir District Original Revenue is already good, because it has carried out its duties and functions in accordance with the stated objectives so this has led to the performance of market retribution employees. The results of this study are also in line with the research of [3][4][5] where leadership has a significant effect on improving employee performance.

\subsection{The effect of incentives on merchant satisfaction}

The results of the second hypothesis test indicate that incentives have a significant effect on the performance of the Pelita market retribution employees, Bangko District, Rokan Hilir Regency. The view of Wibowo (2012) states that incentives have a relationship with employee performance because every job that has provided the best performance must expect rewards in addition to salaries or wages in addition to incentives for the achievements they have given to the company. Thus, if the organization can provide it, it will increase motivation, participation and build mutual understanding and trust between workers and superiors. Material and non-material incentives have a positive and significant effect on employee performance results. Handoko (2001) The term incentive system is generally used to describe wage payment plans that are directly or indirectly related to various employee productivity / performance standards or organizational profitability or both criteria. Therefore, employees who work under a financial incentive system means that their work performance determines, in whole or in part, their income. Likewise with the staff of the Pelita market retribution, Bangko District. The management of the Pelita market retribution in Bangko District has been well coordinated by the Rokan Hilir Regency Market and Trade Industry Service. For the issue of market charges, a special officer has been appointed to handle the activity. Meanwhile, for other activities such as the issuance of market retribution tickets and also the orderliness of Pelita market traders, the Rokan Hilir Regency Trade and Market Industry Office has coordinated with the Rokan Hilir Regency Regional Revenue Service and the Rokan Hilir Regency Civil Service Police Unit. From the research results it is known that there is no incentive for collectors of market levies (iner) provided by the Regional Government of Rokan Hilir Regency. 


\section{CONCLUSION}

The conclusions that can be drawn from the results of research that have been conducted include: the variable leadership has a significant positive effect on the performance of market retribution employees. in other words, better leadership will improve employee performance and the incentive variable has a significant positive effect on the employee performance of market retribution. Through the results of this research, it can be suggested to the management of the Rokan Hilir Regency Market and Trade Industry, which previously only carried out indirect supervision and only relied on written reports only to pay more direct attention to employees working in collecting market fees. In addition, leaders also need to manage incentives well, considering that most of the retribution employees consist of honorary employees who have minimal income.

\section{ACKNOWLEDGMENTS}

This study is Research Grants by The Ministry of Research and Technology/the National Agency for Research and Innovation of the Republic of Indonesia year 2020

\section{REFERENCES}

[1] S. Musyarofah, and T. Agustin, "Analisis Efisiensi dan Efektivitas Pengelolaan Retribusi Pasar di Pemerintah Daerah Kabupaten Gresik" vol. 3, no. 2, pp. 128-138, 2007.

[2] S. Murtiani, D. Kurniadi, and I. M. I. Subroto, "Sistem Informasi Retribusi Pedagang Pasar Kabupaten Semarang," J. Transistor Elektro dan Inform. (TRANSISTOR EI), vol. 1, no. 1, p. 13, 2016.

[3] M. Sugianto, “„Evaluasi Gaya Kepemimpinan CEO Dalam Mencapai Kesuksesan Start-Up Business Maha Siswa Di Universitas Ciputra "e," $J$.
Manaj. Dan Start-Up Bisnis PERFORMA, vol. 3, 2017, [Online]. Available: https://journal.uc.ac.id/index.php/performa/article /view/716.

[4] E. Vigoda-Gadot, "Leadership style, organizational politics, and employees' performance: An empirical examination of two competing models," Pers. Rev., vol. 36, no. 5, pp. 661-683, 2007, doi: $10.1108 / 00483480710773981$.

[5] T. W. H. Ng, "Transformational leadership and performance outcomes: Analyses of multiple mediation pathways," Leadersh. Q., vol. 28, no. 3, pp. 385-417, 2017, doi: 10.1016/j.leaqua.2016.11.008.

[6] Y. Garbers and U. Konradt, "The effect of financial incentives on performance: A quantitative review of individual and team-based financial incentives," J. Occup. Organ. Psychol., vol. 87, no. 1, pp. 102-137, 2014, doi: 10.1111/joop.12039.

[7] M. S. Hasibuan, "Manajemen Sumber Daya Manusia", Jakarta, Indonesia: PT. Bumi Aksara, 2008.

[8] A. Nitisemito, "Manajemen Personalia Ghalia”. Indonesia. UGM, Yogyakarta, 2008.

[9] K. Sudarmanto, "Pengembangan Kompetensi SDM”. Yogyakarta: Pustaka Pelajar, 2009.

[10] A. P. Mangkunegara, "Perilaku Konsumen edisi revisi”. Bandung: Refika Aditama. 2002

[11] F. O. Walumbwa, J. J. Lawler, and B. J. Avolio, "Leadership, individual differences, and workrelated attitudes: A cross-culture investigation," Appl. Psychol., vol. 56, no. 2, pp. 212-230, 2007, doi: 10.1111/j.14640597.2006.00241.x. 